Precarious lives, precarious care: young men's caring practices in three coastal towns in England.

\title{
Precarious lives, precarious care: young men's caring practices in three coastal towns in England.
}

\author{
Abstract \\ A decade of austerity and cuts to local services have had severe impacts on coastal \\ towns in England, resulting in high levels of inequality and precarious employment \\ prospects for many residents, including young men growing up in working class \\ families. Forms of care typically provided by the family and the state are becoming \\ unavailable, and access to secure employment has become difficult, especially for men \\ with few educational qualifications, skills or work experience in places where work is \\ seasonal. In this article we explore the effects of austerity and precariousness on the \\ daily lives of 30 young men living in coastal towns, focusing on the ways they have \\ come to care for each other. We build on feminist efforts to 'trouble 'care, highlighting \\ unexpected caring practices, as well as the conflicts that shape barriers to care and the \\ ways care itself may play out in careless ways, shaped by the austere contexts of its \\ enactment. We pay attention to the significance of place and the everyday spaces in \\ which care is practiced, as well as the ways in which friendship networks are \\ paradoxically both caring and careless
} Keywords: care, masculinity, emotion, austerity, precarity

\section{Introduction: care, austerity and masculinity}

State-implemented austerity measures in the UK over the last decade have resulted in rising inequality, associated with vulnerability, insecurity and precarity. In the UK, funding for social infrastructure such as health, education, childcare, social housing and lifelong care has continually declined (Pearson and Elson 2015, 26), including cuts to 'caring' services (62\% between 2008 and 2017) (Johnsen, Cloke, and May 2005; Clayton, Donovan, and Merchant 2015; Pearson and Elson 2015). Homeless shelters, employment support, women's refuges, youth services and childcare have largely disappeared. These cuts, coupled with significant changes to employment opportunities in terms of growing insecurity, part-time and zero 
Precarious lives, precarious care: young men's caring practices in three coastal towns in England.

hours contracts, and low wages, have had an adverse impact on the living standards of the least affluent.

Working class people living in places that rank highly on indicators of deprivation currently are most adversely affected by rising levels of inequality (Stenning 2018; Horton 2016; McDowell and Harris 2018; Jupp 2017; Hall 2018). Working class families often struggle to care for and support their dependent children, especially teenagers and younger adults who are unable to access permanent work in many cities and towns in the UK, not only in areas where manufacturing has largely disappeared but increasingly in coastal towns, which now rank highly on deprivation indexes (Corfe 2017; Jupp 2017). The lack of secure work for young working class people combined with growing poverty in the home has resulted in, especially for young men, a rise in homelessness, including 'hidden' homelessness such as sofa surfing, living with friends and relatives, as well as visible street homelessness (McLoughlin 2013; Jupp 2017; van Lanen 2018). 100,000 young people, for example, reported themselves homeless in the 2017/2018 financial year (Centrepoint 2018). In these landscapes, young people themselves are undertaking more emotional work to cope with the precarious nature of austerity (Pimlott-Wilson 2017).

For white working-class men, with low rates of access to higher education and higher than average rates of unemployment, austerity has had particularly severe effects. Increasingly, ways of replacing formal and familial forms of care depend on networks constructed through local friendships. Enacting practices (seeking, receiving and giving) of care, however, are seldom considered attributes of embodied performances of masculinity (Nayak 2006; England and Isabel 2014), especially among young working class men (Connell 2000). These men are typically seen as tough and aggressive, or alternatively as likely to suffer in silence, so increasing their precarious situations. However, responses to austerity and insecurity may have contradictory effects. Power and Hall $(2018,311)$ suggest 
Precarious lives, precarious care: young men's caring practices in three coastal towns in England.

that 'new spaces, relations, networks and practices of care and caring are emerging in difficult times, in unexpected and unconventional places'. Tarrant (2018) argues that men in low to middle income families have had to reimagine themselves as caring and carers in austere times, suggesting that austerity may bring new relationships within and outside families and households, remaking gendered relations as young men come to rely on one another in new ways. It is in these conversations that we situate our work, exploring whether and in what form caring practices emerge for and between young white working class men, understanding working class masculinities as changing and evolving in particular contexts (Roberts 2012). This is not, however, an argument that absolves responsibility from right wing governments, nor a claim that personal or class-based forms of solidarity are a sufficient response to the current political situation.

In this article, we examine precarious caring practices among 30 young, white, working-class men who we interviewed in South Shields, Southport and Ilfracombe, UK, in 2018 and 2019. Struggling with rising inequality and declining services, many families in these towns are increasingly unable to provide emotional or financial support for their older children and, in some cases, reluctant or unable to provide a home. In these circumstances, caring practices became significant amongst the young men and their friends, providing places for each other to stay, and deepening their bonds of friendships as ways of coping with austerity. Whilst some of these may seem like mundane acts, we argue they are caring practices when understood in the context of austerity, precarity and marginalisation, creating new patterns of care among a group of people who are assumed careless. We draw on feminist understandings of care and precarity to highlight how care takes shape amongst young working-class men when faced with hardship, worklessness and state-implemented austerity. Doing so, we appreciate the importance of power relations to argue that care is shaped by the austere contexts that it is enacted, meaning that care itself becomes precarious. 
Precarious lives, precarious care: young men's caring practices in three coastal towns in England.

We contribute to feminist geographies by continuing efforts to trouble understandings of care, disrupting widespread associations between femininity and caring (Walby 1986; England 2010).

The argument that follows is in four parts. First, we review the largely feministinspired literature about precarity and care, demonstrating how care may be precarious. Secondly, we explain the choice of coastal towns as sites for the research and outline the research methods. We then explore two aspects of the relational practices of care among the men to whom we talked: first, the significance of place, especially the particularity of coastal resorts, followed by an exploration of the positive and negative impacts of friendships that provide both personal support and other forms of care, as well as less positive relationships. We conclude by outlining our contribution to feminist geographies of care.

\section{Precarious living, care and conflict}

In our focus on the relationship between austerity, vulnerability and care, we draw on Butler's (2004) theorisation of precariousness. For Butler, vulnerability is part of the human condition. All lives are vulnerable, and precariousness is felt and experienced by people when their lives are made vulnerable by institutions, discourses and circumstances. Not all lives become precarious in the same ways across time and space as shifting arrangements of gender, sexuality, race, class, ability, age and nation, as well as varied levels of support, protect some from adverse circumstances. Different lives are more 'valued' in different societies and not all lives are deemed worthy of care. Since the 2007/8 financial crash and subsequent austerity programmes implemented by the UK government, precarity is an increasingly lived and harsh reality. Standing (2011) and others (Bloodworth 2018; Prassl 2018) focus on the economic implications of the crisis and austerity, documenting the transformations in working lives as zero-hour, platform and gig employment with low or 
Precarious lives, precarious care: young men's caring practices in three coastal towns in England.

unstable pay have become increasingly common, especially for the most vulnerable (Hardgrove et al 2015; McDowell 2017). Engaging with Butler's theorisations and work by feminist geographers (see Johnston 2018 for review), however, we understand austerity as more than an economic phenomenon but as a wider social and cultural condition with multiple and unstable affects, including the emotional consequences of living with insecurity. Austerity creates constant uncertainties and precarities that are lived, felt and negotiated in different ways across space and time, including anxiety and depression but also perhaps feelings of belonging and solidarity (Hall, 2018).

When people feel vulnerable, they often seek some form of care, not only from state and voluntary service providers (if available), but also from individuals and groups, including family and friends. Fisher and Tronto $(1990,40)$ define care as 'a species activity that includes everything we do to maintain, continue and repair our 'world' so that we can live in it as well as possible'. Care may be understood as a set of practices undertaken to ensure the wellbeing of others and places, from different forms of material help to emotional support. Caring practices are part of paid and unpaid work. Care may be provided formally by market and voluntary institutions (Bastia 2015; Held 2005; England and Henry 2013), and informally on the basis of individual or group assistance. Caring practices operate from the scale of the body to global circulation through transnational organisations (Parr 2003; Ehrenreich and Hochschild 2003; Thompson 2019). These practices are not simply public or private but transcend and connect the division (Staeheli and Brown 2003; Sihto 2018).

Feminist scholars have critiqued and troubled the concept of care as homogenous (Bondi 2008; McEwan and Goodman 2010; Raghuram 2016; Bartos 2018; McDowell 2004; Raghuram, Madge, and Noxolo 2009). By examining the gendered politics of care, feminist researchers have highlighted how caring practices in the home, while typically considered 'women's work', are fundamental to the function of capitalist processes (Walby 1986; 
Precarious lives, precarious care: young men's caring practices in three coastal towns in England.

McDowell 2005; England 2010). As geographers have argued, the places through which care is practiced also matter (Parr 2003; Conradson 2003; Milligan and Wiles 2010). Care takes shape through the contexts, places and spaces in which it is enacted, performed and embodied (Bartos 2018; Conradson 2003; Milligan and Wiles 2010).

Raghuram (2016), drawing on a critical postcolonial framework, argues that many analysts fail to explore the diversity of care and caring practices - care can take different forms and have different outcomes for different bodies. Bartos $(2018,72)$, drawing on Raghuram, develops these ideas, stating:

Caring ... can be directed toward, and exist between, any person or group of people. However, care is not always positive. In fact, exploring care beyond traditional caregiving relationships helps to demonstrate that care can result in active and passive care-less outcomes ... Uncovering the diversity of caring practices beyond normative examples is one way to trouble care and illuminate the complicated relationalities of care.

As Bartos $(2018 ; 2012)$ notes, to understand care, care and conflict need to be held in tension, appreciating the power dynamics that shape care.

In our exploration of care and precarity, we pay specific attention to the relations of power that produce how care is enacted, embodied and practiced. The relationship between care, power and austerity has become a significant research focus since the financial recession in 2008 and the roll-out of a programme of cuts by successive governments since (McDowell 2017; Hall 2018; Tarrant 2018; van Lanen 2018). Johnsen, Cloke and May (2005) argue that due to austerity, caring spaces for the homeless can become spaces of fear, not only for the homeless but also for workers and volunteers, reflecting the uncertainties and power relations that are involved. Clayton, Donovan, and Merchant (2015) highlight the ways in which people employed in care services become committed to negotiating the cruelty of austerity through the complex emotional labour they undertake in their work but forced to cut 
Precarious lives, precarious care: young men's caring practices in three coastal towns in England.

corners or make compromises as staff and services are cut. Emotional labour typically is given little value or recognition, yet it is essential to the lives of many in the UK. Under pressure, workers in care services may become even more committed to the emotional aspects of their daily tasks, to the 'accepted feature of these occupational identities' (Clayton, Donovan, and Merchant, 2015, 28). At the same time, however, care work may not always be 'caring' but involve moral judgements or enforcement of particular practices. As Marquardt (2016) argues certain services (for example, social work) involve enforcing particular ways of living (for example, hygiene and routine) that may be ways for the state to enact control over vulnerable bodies.

Austerity has specifically gendered consequences (Karamessini and Rubery 2014; Power and Hall 2018). Although male unemployment rates may have increased faster than women's (Razzu and Singleton 2018), austerity has had devastating effects on women who typically are more reliant on state welfare services and the providers of both informal and formal care (MacLeavy 2011; Elson 2012; Pearson and Elson 2015). Feminist economists have demonstrated how austerity has affected the most vulnerable women in the UK (Emejulu and Bassel 2015; Greer Murphy 2017; Jupp 2017; Pearson and Elson 2015). Hall's (2018) ethnographic work in Greater Manchester highlights how the emotional and material work that is involved in repairing the people and places impacted by austerity falls on women. This repair work, Hall argues, fosters corporeal and emotional togetherness, helping people 'manage' austerity. However, as many women live in households with partners and children, the effects of austerity are felt not just be individual women but by the household as a whole.

The particular connections between austerity, men's lives and relations of care have had relatively little attention so far. In previous studies of young white working-class men in England, the family has typically been the focus when analysing the relations of caring. 
Precarious lives, precarious care: young men's caring practices in three coastal towns in England.

McDowell (2014), for example, in a study of Luton and Swindon, argues families, specifically mothers played an important part in supporting and caring for young men during periods of worklessness or casual and precarious employment by, for example, washing work uniforms, providing meals and emotional support. Men, perhaps especially young single men, are rarely encouraged to care in the same ways as women, whether at work, at home or with friends (McDowell 2005; Conradson 2003; Elliott 2015). In academic research on masculinity, care is typically understood to be 'outside' the boundaries of hegemonic versions of masculinity (Connell 1995; Connell and Messerschmidt 2005), although some scholars have argued that hegemonic masculinity and care may become intimately associated. Jordan (2018), for example, highlights how Fathers Rights Groups in England use the notion of 'caring masculinities' to construct men as 'better' child rearers than women. Such narratives and embodiments attempt to masculinise care, rather than reconfiguring masculinity as caring (Jordan 2018; Eisen and Yamashita 2017; Allen 2007). Whilst masculinising care may shift the boundaries of masculinity, it does not disrupt dominant or traditional gender roles (Johansson and Klinth 2008): masculinity is not easily disrupted by men becoming caring. Elliot (2015) develops a 'practice-based model', drawing on feminist theories of care and critical studies of men and masculinity, arguing that the boundaries of masculinity must be redrawn to include emotion, care and sensitivity, as a way to dismantle patriarchal power structures and relations.

Masculinity and its connections with relations of care must also be understood in specific temporal, geographic, social and cultural contexts (Berg and Longhurst 2003; Longhurst 2000; Hopkins and Noble 2009). Tarrant's (2018) work, for example, is important in highlighting how men in the north of England have both come to care and to neglect familial caring relations due to austerity. England and Dyck $(2014,295)$ argue that exploring the relations between 'masculinities, embodiment and care opens up and expands future 
Precarious lives, precarious care: young men's caring practices in three coastal towns in England.

possibilities for expanding the research on the lived experience of men'. It is this challenge that we accept here. We now turn to the details of the empirical research.

\section{Interviewing young men in coastal towns}

Coastal towns are now among the most deprived towns in the UK (Corfe 2017) but have received less attention than large cities or declining manufacturing towns where the effects of cycles of poor paid work and worklessness are well-known (Shildrick and MacDonald 2012). Long sites of casualised and seasonal employment, the employment outlook for young people has become even harsher since the economic crisis and austerity programmes. Rates of homelessness have increased and these towns have exceptionally high rates of drug use (Corfe 2017). To explore the extent of young men's responses to austerity, we interviewed ten young men in each of the three towns: South Shields in the north east, Southport in the north west and Ilfracombe in the south west. In each place, traditional male employing industries such as fishing and shipping have declined significantly and little alternative employment has been attracted, despite regeneration efforts. The affordability and expansion of foreign travel in post-war decades (Rickey and Houghton 2009; McDowell and BonnerThompson 2019; Corfe 2017) had a negative impact on English resorts and tourism has remained stubbornly resistant to expansion. Each town has a shortage of inexpensive stateprovided housing to rent, no institutions of higher education and, apart from South Shields, poor transport connections with the hinterland. Youth unemployment is two or three percentage points higher than the national average in each place and young men are often seen as unsuitable employees in the customer-facing service industries that now represent the main employment opportunities in resorts. The similarities between the towns are thus marked. Nationally, young workers are disadvantaged by age discrimination ineligibility for the national minimum wage. The hourly rates (in April 2019) were $£ 6.15$ for 18 -20 year olds, 
Precarious lives, precarious care: young men's caring practices in three coastal towns in England.

$£ 7.70$ for $21-24$ year olds and $£ 8.21$ for people aged 25 and over. For those who were unemployed controversial changes in income support combining a series of separate payments into a single Universal Credit has further disadvantaged young people with few skills, low financial resources and little access to the internet as the system is online only.

While the key aim of the larger study, of which this article is a part, was to explore the search for employment of young men aged between 18 and 24, it became apparent that securing decent work was an illusion for many of the participants. In their stories, coping with homelessness, isolation, street violence and depression was central. Networks of friends that provided both positive support and involvement in more destructive practices became a common theme. The interviews were undertaken by Carl between November 2018 and April 2019, based on a set of issues that we both identified and interviews conducted in Hastings, a coastal town on the south coast of England (McDowell and Harris 2018). All participants were white British, aged 18-24 and identified in various ways, including through drop-in centres for young people, youth charities, local colleges, homeless services and shelters and drug and alcohol services. Carl also 'hung out' locally, in pubs and on the streets leaving flyers and speaking to local people, as well as using community Facebook groups. Advertisements were posted on 'looking for work', 'selling stuff' and 'gossip' Facebook groups. In each case, we asked permission for access to these groups, and to all participants explaining the research and promising confidentiality. Each interviewee was paid $£ 20$ for participating.

Paying participants for their time is a complex decision as it changes the relationship between participant and researcher (Hammett and Sporton 2012). However, contacting people who have been hit hard by austerity arguably leaves researchers with a duty of care (Hall 2017). Hall chose not to pay participants when conducting ethnographic research on austerity in Greater Manchester, providing instead small gifts and emotional support and 
Precarious lives, precarious care: young men's caring practices in three coastal towns in England.

advice to the families she worked with. However, her research was longitudinal, whereas ours was not and so longer-term support was not possible. While a financial payment may be problematic, it leaves the recipient with a choice of how to spend it and felt less directive than offering a different form of recompense.

The interviews were conducted in local cafes, or in the offices or other spaces of local organisations. We explored their lives chronologically from school years to the present, asking about home, school, and social lives, about precarious work situations and how they have coped with periods of insecurity and hardship. Pauses, bodily discomforts, embarrassment and evident expressions of unease and shame were noted and issues were not probed if discomfort was evident. All interviews were recorded and transcribed in full. They were thematically analysed using NVivo, drawing on previous studies of masculinity and austerity and common themes across the three sets of interviews as the analysis proceeded.

At the time of the interviews, 14 of the 30 young men were unemployed, four had a formal work contract, and eight attended some form of college course or training. The remaining four were in precarious, cash in-hand or temporary work, including gardening and labouring. For 15 of the 30 young men in our study sleeping in tents in public space, on the streets, on friends' sofas and/or in homeless hostels was an accepting, if not acceptable, part of leaving home. Some to the men had experienced periods in care-homes during their school years. A sizeable proportion of the men also reported that they lived with mental health issues, including depression and anxiety, and a smaller number lived with autism and ADHD.

In the analysis, it emerged that the young men had little family support, reliant on friends rather than parents or other relatives, or on formal organisations such as statutory social services or youth charities during difficult times. However, as we document in more detail below, mutual care was neither easy nor continuous, often disrupted by the precarious circumstances of the participants. Practices of reciprocal support were hard to sustain by men 
Precarious lives, precarious care: young men's caring practices in three coastal towns in England.

with few financial resources and often in emotional distress. In the following sections, we explore the emergence and shape of caring relations, focusing first on the significance of place, followed by an analysis of friendships.

\section{Care, masculinity and place}

For many of the young men in this study, practices of care were deeply rooted in the places that they lived in and frequented. The particularity of certain places, street corners, drop-in centres and leisure spaces were mentioned. However, it also emerged that the coast itself the natural environment and the specific versions of masculinities that are common in working class seaside towns - were an important part of the social construction of selfidentities and feelings of responsibility for other young men. Seaside towns in England have a reputation among young men as places for excess, pleasure and violence (Cohen 1972; McDowell and Bonner-Thompson 2019). However, for young men who live in these towns, rather than the summer visitors, the feeling of being left behind is stronger than the sort of swaggering captured in Connell's (2000) notion of a transgressive youthful masculinity.

The young men in this study were thoughtful about their understanding of stereotypical views of men as unemotional and uncaring and in conversation explained the conflict they felt between adherence to conventional views and a desire to be more open about their feelings.

Joe and Kyle explain this conflict:

I'm not saying this in a sexist way, but I feel that men are more, like, sometimes like... men are more vulnerable. Like men don't like to show their emotions... like some people think that like if men show their emotions they're like weak and that, but it's not the case. They're strong really, aren't they? Interviewer: do you feel you can show emotions to your friends? Joe: I don't know about me friends like, I feel embarrassed ... just me friends, I don't want to put them in a bad mood, so I just think, keep it to me self. 
Precarious lives, precarious care: young men's caring practices in three coastal towns in England.

(Joe, 19, South Shields)

I just hold it in myself, and just deal with it. If I told my friends they probably wouldn't take me seriously because I'm just the joker of the group sort of thing, and then yeah, so they wouldn't believe me. A friend that I've been friends with for 17 years, he's ok, like I can tell him a few things, not a lot... I don't know, I just think they would just take the mick, cos their lives are so much better, or they just wouldn't take me seriously. (Kyle, 18, Ilfracombe)

Joe and Kyle's comments show that expressions of vulnerability are not easily revealed in public places, even when among friends. Joe was aware that men are not encouraged to talk about their feelings and recognises this as one of the barriers that prevent him from seeking an emotional connection and possibly support from his friends. The fear that friends may be judgemental or not take them seriously inhibits them, leaving them conflicted or as Kyle so movingly notes putting on a fake face and so left to deal with emotional distress alone. For these men, austerity has not resulted in the redrawing boundaries of masculinities as suggested by Tarrant (2018), but the maintenance of stereotypical attributes and behaviours. For white working-class men, offering care and the expression of emotions are not part of acceptable versions of embodied masculinity based on physical strength, once essential for manual labour (Nixon 2009). Although manual labour is disappearing in the UK, being physically strong and showing little emotion, still shapes working class masculinities. As austerity measures in the UK have left many young workingclass men without work, especially in occupations that might be coded masculine, a particular form of embodied strength is still seen as a way to embody masculinity (Nayak 2003; McDowell 2003). As secure work recedes for these men, constructing a tough unemotional performance becomes one of the only ways of demonstrating an acceptable masculinity. Seeking, or even providing emotional support and care often becomes difficult as young 
Precarious lives, precarious care: young men's caring practices in three coastal towns in England.

working class men hang out in the conventional spaces of open to them in seaside towns - in arcades, cheap bars and in open spaces, including the beach.

Ben develops this, explaining the places he frequents and the paradoxical emotions they elicit. He compares his childhood excitement and perhaps the lost security with his current reactions, unable to open up to his friends even though they seem to offer support:

I like the town centre... I like the little arcades and all that, I just like being a big kid, it brings back memories, that I can smile about ... and then just walking around Southport, I get depressed. There isn't anything I can smile about. All me mates are just like, what's up? And I don't like talking to them about it. I know they're me mates, but they could be judgemental, they could go home and could talk to their parents about it.

(Ben, 22, Southport)

Young men are reminded of the hardships they experience as they move through the places where they live. Ben finds Southport 'depressing' as its deteriorating townscape becomes an emotional reminder of austerity, worklessness and precarious living. The claim that the built environment of these coastal towns is depressing was echoed by many of the participants.

In spite of this, the landscape, especially the beach and the cliffs, was a significant factor in coping, providing feelings of emotional security.

My friends get together; we'll go rock climbing. We're out of the way, we're not doing any harm, it makes us feel better... for me personally, it's like in nature. That's how I am, for me I find peace in nature. Just going down to the sea and sitting there for 10 minutes, it all goes over my head, (Steve, 24, Ilfracombe)

Finding solace in the natural environment was a common theme, as Joe and Craig explained. 
Precarious lives, precarious care: young men's caring practices in three coastal towns in England.

I just like going along the beach for walks, or just lying there, sometimes drinking on the beach, I just like it. I just like South Shields. We've got a lovely beach; we're so lucky to have it. I just like chilling on the beach listening to the waves. It makes us relaxed, you know. It makes us not care about anything in the world.

(Joe, 19, South Shields)

If you go to places like Ainsdale, Birkdale, Formby [villages on the edge of Southport], like you go and sit on dunes and watch the sunset. I dunno, it's just nice, the environment... sometimes, me and my mates, in the summer, we'll just get a few beers and go sit on the sand dunes and go and chill out and listen to a bit of music and have a little barbeque or something...

(Craig, 20, Southport)

The ocean, rocks, and coastline provide a space where these young men hang out with their friends, relatively free from the forms of surveillance they are usually subjected. In these open spaces, they feel more able to cope with the precarity of their lives, creating affective ties between them and the places where they feel more able to reveal their emotions, providing spaces of care for each other. Friendships are crucially important when formal systems of care have broken down. The emotional interdependence between men and place shows both how austerity and precariousness create the need for care. The beaches and open spaces of coastal towns emerge as places of hope and support (Power and Hall 2018; Hall 2018), while existing alongside the reminders of precarity, declining opportunities and distress visible in the built environment. Examining the geographies where caring practices occur highlights how people cope with austerity. Here, the natural environment of coastal towns becomes important for the young men in feeling that they are cared for. Central to this attachment to place are the friendships between the young men. However, as we demonstrate in the next section, friendships may be contradictory, providing both care and emotional resilience but also leading to involvement in destructive activities, especially drinking and drug taking. 
Precarious lives, precarious care: young men's caring practices in three coastal towns in England.

\section{The contradiction of friendships and care}

As the discussion already indicates, friendships provide emotional support for some, even when some men find it hard to be open about their emotions. What is crucial, however, is the practical support provided by friends, aiding young men to react to, and perhaps tolerate, state-implemented austerity and insecure employment. Greg highlights the importance of friendship when he says:

My friends have got me through loads in this time, when my family haven't been there for me... it makes me want to stay here ... it's good to have friends you can rely on. (Greg, 24, Ilfracombe)

14 of the 30 young men told us how friends provided places to stay when they were homeless.

Yeah, my friend Steve, who is a very good friend of mine, and his brother, they actually put me up and they helped me get a flat, they helped me a lot. I feel like if you don't have friends round here you really are stuck in a loop. You are gonna be screwed. (Greg, 24, Ilfracombe)

Well, one of the lads, I actually took them in myself when he was homeless ... He had a girlfriend. And they took me in.

(Steve, 24, Ilfracombe)

Me and me mum were going through a bit of shit... me ma' kicked me out, and then I kind of just got in touch with me mate and said 'can I stay at yours?'. Kind of just went from there really, until me and him started getting in arguments.

(Jacob, 20, Southport)

For these young men, family support systems had broken down through issues including mental health, drugs and alcohol. They were fortunate to have friends with whom to stay when they first became homeless. There has been the widespread withdrawal of services and support for young people, including coastal towns in England (Stenning 2018; Horton 2016; 
Precarious lives, precarious care: young men's caring practices in three coastal towns in England.

McDowell and Harris 2018; Jupp 2017), although as Steve notes there never has been generous support in Ilfracombe: 'because it's such a small place, there's only a limited amount of support. So it is either relying on your friends, or wait for the council until they can sort something'. Other men also documented the forms of material support and care provided by their friends. Here Gary, 21, also living in Ifracombe, explains the gratitude he felt towards a friend: 'I was sleeping in the tent, but I had my mate. He let me stay at his for a few nights a week, have a shower and that'.

Safe and accessible housing is a basic requisite of a decent life (Clarke 2016), but as we found it is one that is not accessible to too many young people with little financial security. Sofa surfing (staying with friends on a limited basis) may be a partial resolution, although it often exacerbates insecurity, as it is a temporary and so precarious solution. Steve talks about places where he sofa surfed, being taken in by his friends and staying with men who lived in similarly precarious situations to him.

\footnotetext{
It was going around other friends, who were unfortunately very, mentally impaired, basically, and it was very grimy and horrible. That was even more depressing really, but it was very kind of them to let me in their home. But all in all it was just a bit shit being homeless here.
}

(Steve, 24, Ilfracombe)

For Steve, the care that his friends exhibited did not necessarily feel supportive as he felt both beholden and precarious. Often sub-standard, temporary accommodation is a material reminder of the insecurity of its occupants, exacerbating, for Steve and others in the same position, feelings of depression and sadness rather than care.

For Andy and Ben, dependence on friends who offered a bed for a period, sofa surfing was not only a symbol of need but led them into drug-related poverty: 
Precarious lives, precarious care: young men's caring practices in three coastal towns in England.

So, I rang him up and said, 'can I stay at yours for a few weeks, me ma's kicked us out?', 'why aye mate, no bother'. He was a really bad legal high addict. He was doing really well for himself. He got himself off it, right. He was just smoking the bud [marijuana] and that, drinking the cider and that. Until one day he come home and that, he'd be struggling to get $£ 10$ for a smoke. And we've looked at each other, and said 'should we just buy a gram [of spice] and have the occasional joint?' 'Aye, that sounds like a good idea, right' ... Spice ${ }^{1}$, right, but obviously cos it all went underground [made illegal], we were basically smoking smack [heroin], and we didn't know..

(Andy, 18, South Shields)

At the age of 14 I argued with me mum once and she told me to get out the house. She kicked me out the house that day. So, obviously, I've had to turn to mates, but then mates have put me in the wrong direction then, by asking me to do stuff for them. Because, since I was 8, I've smoked weed. And the mates I've chilled with are a lot older than what I actually was at the time. These had already left school, and these had already picked what they wanted to do, and that was sell drugs... I'm on the streets at 14 . What am I gonna do? So, the first thing I did, I went to him and I asked him for help. It was like, no matter what the risk is, I've got to take... So, started selling crack [crack cocaine], heroin.

(Ben, 22, Southport)

While it may be hard to see these circumstances and behaviour as the provision of care, to the men involved, to a degree, they were conceived as support. For both Ben and Andy, friends provided them with somewhere to sleep, for which they were grateful. However, the consequence was involvement for several years in other taking and selling illegal drugs. At the time of the interview Andy was still addicted to spice but was trying to recover. Ben was clean and attempting to earn a living without selling drugs.

The relationship with drugs and alcohol is complicated. For some of these young men, bonds were formed (and broken) through such consumption. In the following extracts,

\footnotetext{
${ }^{1}$ a term used for a range of laboratory-produced psychoactive chemicals that are constantly modified to when a previous version is classified illegal. In May 2016 the production and sale of psychoactive substances became illegal.
} 
Precarious lives, precarious care: young men's caring practices in three coastal towns in England.

Eddie and Sam reveal that their group of friends had a reciprocal arrangement, buying drugs and alcohol to share, including the men who were out of work at any one time.

It was $£ 127$ (a pay cheque). I thought it was gonna last me for ages; that's loads of money. It's not. It used to go by the weekend ...I was the only one getting paid. I used to look after them [friends]. ... just like pay for things for them and that. You know when we were all skint, he [points to Sam] was working, he would also make sure we were all right. So, me mam would say 'you've spent all your money on your mates', cos these are the people who would look after me when I was skint... I was spending it on everyone. I was buying loads [alcohol and drugs].

(Eddie, 19, South Shields)

This practice enabled the friends to party together, without excluding men without an income. Eddie, with Sam interjecting, continued:

Every Friday.... there's a bridge. 30, 50 people used to go, used to snap glow sticks, put them everywhere. There was a big speaker. It was mint. It was under a bridge, a big massive speaker, used to echo with the sound ... and you would be walking along covered in glow sticks, and people walking about sweating. It was class. It was the times of me life. I used to fall asleep, shaking,

Sam: Six jackets on, fast asleep.

Eddie: We used to go round about now - October, November, freezing. We would take cowies [ecstasy tablets] and that, sweating.

(Eddie, and Sam, both 19, South Shields).

For Eddie and Sam enabling each other to party was a way to build bonds of friendship. As they told this story, they laughed together. Sweating and shaking are physiological reactions to certain drugs - particularly ecstasy. The embodied dimensions of sound, sweat, temperature and proximity of bodies combine to create affective and emotional ties of friendship that would enable them to negotiate the harsh realities of austerity together. Binge spending, however, left the men without money for everyday expenses, exacerbating their precarity as they were left without resources to look for work. 
Precarious lives, precarious care: young men's caring practices in three coastal towns in England.

Addiction to drugs and alcohol is a significant problem in seaside towns, exacerbating the structural circumstances that create the inequalities surrounding young men. The spaces of care informally created by and for young men both alleviate some of their distress but may also deepen their precariousness as Johnsen, Cloke, and May (2005) have argued. New patterns of care may be emerging among young men living with austerity (Power and Hall 2018) and may provide some temporary alleviation from the hardships of everyday life but their effects are often contradictory, as we have documented here. Precarious friendships are insufficient compensation for the withdrawal of state-provided services.

\section{Conclusions}

We have highlighted here how new patterns of care are emerging for young men who are negotiating the precarious and uncertain realities of austerity in coastal towns in England. We focused on undocumented practices of care amongst a group of people that are assumed careless. By understanding young men's friendships as care, we explored new and unexpected ways that young people are responding to austerity, whilst also challenging assumptions that young working-class men are unable to care. Nevertheless, new caring practices are unstable and precarious due to the uncertain conditions affecting these young men. Care, when entangled in relations of power and control as well as inequality and disadvantage, is seldom a remedy for vulnerability and precarity.

Highlighting the precarious nature of care, we have made two contributions to feminist and youth geographies. First, in the focus on informal care systems and reciprocal efforts among young men to support one another when they feel vulnerable, we uncovered both the ways in which emotional support is shared as well as the barriers to caring for each other that are constructed through the intersection of the social construction of masculinity and changing structural circumstances. Secondly, we provided an outline of the significance 
Precarious lives, precarious care: young men's caring practices in three coastal towns in England.

of place, showing how the natural environment of coastal towns not only exacerbates feelings of despair but also provides succour and emotional support. In these arguments - about sociality and spatiality - we reveal the relations of power that shape the development of caring practices. Care is intimately connected to feelings of being beholden and solidarity includes reciprocation, which is not always easy for those with few resources. Material resources - money and places to sleep - as well as emotional resilience are key to being able to offer and accept care.

Coastal towns in England have amongst the highest rates of drug use and dependency in England and it is depressingly clear from the interviews how drug use is implicated in the (in)ability to provide care for others and for the self. Yet, drug use is often an illusion of managing the consequences of worklessness and austerity. Nevertheless, as we have documented, young working class men do, and try to, care for each other, disrupting longstanding associations between women and ethics and practices of care and opening up the research agenda to new questions. In times of austerity, there may be new practices of care emerging between unlikely individuals in unlikely times and places (Power and Hall 2018), fostering corporeal and emotional togetherness (Hall 2018). However, care does not always maintain, continue and repair worlds (Fisher and Tronto 1990) and may lead to further vulnerabilities. Caring practices are shaped by austerity, poverty and precarity in seaside towns. The people most affected by these unequal processes are the people most in need of better public provision, deserving more than reliance on their own resources to respond to structural inequalities, exacerbated by austerity.

\section{References}

Allen, Louisa. 2007. "'Sensitive and Real Macho All at the Same Time': Young Heterosexual Men and Romance." Men and Masculinities 10 (2): 137-152. doi:10.1177/1097184x05284221. 
Precarious lives, precarious care: young men's caring practices in three coastal towns in England.

Bartos, Ann E. 2012. "Children Caring for Their Worlds: The Politics of Care and Childhood." Political Geography 31 (3): 157-166. doi:10.1016/j.polgeo.2011.12.003.

Bartos, Ann E. 2018. "The Uncomfortable Politics of Care and Conflict: Exploring Nontraditional Caring Agencies." Geoforum 88 (January): 66-73. doi:10.1016/j.geoforum.2017.11.010.

Bastia, Tanja. 2015. "'Looking after Granny': A Transnational Ethic of Care and Responsibility." Geoforum 64 (August): 121-129. doi:10.1016/j.geoforum.2015.06.014.

Berg, Lawrence D., and Robyn Longhurst. 2003. "Placing Masculinities and Geography." Gender, Place \& Culture 10 (4): 351-360. doi:10.1080/0966369032000153322.

Bloodworth, James 2018 Hired: six months undercover in low-wage Britain, Atlantic Books, London

Bondi, Liz. 2008. "On the Relational Dynamics of Caring: A Psychotherapeutic Approach to Emotional and Power Dimensions of Women's Care Work." Gender, Place \& Culture 15 (3): 249-265. doi:10.1080/09663690801996262.

Butler, Judith. 2004. Precarious Life. London: Verso.

Centrepoint. 2018. Making Homeless Young People Count: The Scale of Youth Homelessness in the UK. Accessed June 19. https://www.yhdatabank.com/.

Clarke, A. 2016. "The Prevalence of Rough Sleeping and Sofa Surfing amongst Young People in the UK." Social Inclusion 4 (4): 60-72. doi:10.17645/si.v4i4.597.

Clayton, John, Catherine Donovan, and Jacqui Merchant. 2015. "Emotions of Austerity: Care and Commitment in Public Service Delivery in the North East of England." Emotion, Space and Society 14 (February): 24-32. doi:10.1016/j.emospa.2014.11.004.

Connell, R. W. 1995. Masculinities. Cambridge, UK: Polity Press.

Connell, R. W. 2000. Men and the Boys. California: University of California Press.

Connell, R. W., and James W. Messerschmidt. 2005. "Hegemonic Masculinity: Rethinking the Concept." Gender \& Society 19 (6): 829-859. doi:10.1177/0891243205278639.

Conradson, David. 2003. "Geographies of Care: Spaces, Practices, Experiences.” Social \& Cultural Geography 4 (4): 451-454. doi:10.1080/1464936032000137894.

Cohen, Stan 1927 Folk devils and moral panics: the creation of the mods and rockers

McGibbon and Kee London

Corfe, S. 2017. Living on the Edge: Britain's Coastal Communities. London: Social Market Foundation.

Dean, Hartley. 2012. “The Ethical Deficit of the United Kingdom's Proposed Universal Credit: Pimping the Precariat?" The Political Quarterly 83 (2): 353-359. doi:10.1111/j.1467-923X.2012.02292.x.

Ehrenreich, B., and A.R. Hochschild. 2003. Global Woman: Nannies, Maids, and Sex Workers in the New Economy. A Metropolitan-Owl Book. London: Granta Books.

Eisen, Daniel B., and Liann Yamashita. 2017. "Borrowing from Femininity: The Caring Man, Hybrid Masculinities, and Maintaining Male Dominance." Men and Masculinities, September, 1097184X17728552. doi:10.1177/1097184X17728552.

Elliott, Karla. 2015. "Caring Masculinities: Theorizing an Emerging Concept." Men and Masculinities 19 (3): 240-259. doi:10.1177/1097184X15576203.

Elson, Diane. 2012. "The Reduction of the UK Budget Deficit: A Human Rights Perspective." International Review of Applied Economics 26 (2): 177-190. doi:10.1080/02692171.2011.640315.

Emejulu, Akwugo, and Leah Bassel. 2015. "Minority Women, Austerity and Activism." Race \& Class 57 (2): 86-95. doi:10.1177/0306396815595913. 
Precarious lives, precarious care: young men's caring practices in three coastal towns in England.

England, Kim. 2010. "Home, Work and the Shifting Geographies of Care." Ethics, Place \& Environment 13 (2): 131-150. doi:10.1080/13668791003778826.

England, Kim, and Caitlin Henry. 2013. "Care Work, Migration and Citizenship: International Nurses in the UK." Social \& Cultural Geography 14 (5): 558-574. doi:10.1080/14649365.2013.786789.

England, Kim, and Dyck Isabel. 2014. "Masculinities, Embodiment and Care.” In Masculinities and Place, edited by Andrew Gorman-Murray and Peter Hopkins, 285297. Surrey: Ashgate.

Fisher, B, and J C Tronto. 1990. "Toward a Feminist Theory of Caring." In Circles of Care: Work and Identity in Women's Lives, edited by E.K. Abel and M.K. Nelson, 36-54. SUNY Series on Women and Work. Albany: State University of New York Press. https://books.google.co.uk/books?id=d45FAgAAQBAJ.

Hall, Sarah Marie. 2017. "Personal, Relational and Intimate Geographies of Austerity: Ethical and Empirical Considerations." Area 49 (3): 303-310. doi:10.1111/area.12251.

Hall, Sarah Marie. 2018. "The Personal Is Political: Feminist Geographies of/in Austerity." Geoforum, April. doi:10.1016/j.geoforum.2018.04.010.

Hammett, Daniel, and Deborah Sporton. 2012. "Paying for Interviews? Negotiating Ethics, Power and Expectation." Area 44 (4): 496-502. doi:10.1111/j.14754762.2012.01102.x.

Hardgrove, Abby, Esther Rootham, and Linda McDowell. 2015. "Possible Selves in a Precarious Labour Market: Youth, Imagined Futures, and Transitions to Work in the UK." Geoforum 60: 163-171. doi:https://doi.org/10.1016/j.geoforum.2015.01.014.

Held, V. 2005. The Ethics of Care: Personal, Political, and Global. Oxford: Oxford University Press. https://books.google.co.uk/books?id=3uwSL10Xn_AC.

Hopkins, Peter, and Greg Noble. 2009. "Masculinities in Place: Situated Identities, Relations and Intersectionality." Social \& Cultural Geography 10 (8): 811-819. doi:10.1080/14649360903305817.

Horton, John. 2016. "Anticipating Service Withdrawal: Young People in Spaces of Neoliberalisation, Austerity and Economic Crisis." Transactions of the Institute of British Geographers 41 (4): 349-362. doi:10.1111/tran.12134.

Johansson, Thomas, and Roger Klinth. 2008. "Caring Fathers: The Ideology of Gender Equality and Masculine Positions." Men and Masculinities 11 (1): 42-62. doi:10.1177/1097184X06291899.

Johnsen, Sarah, Paul Cloke, and Jon May. 2005. "Day Centres for Homeless People: Spaces of Care or Fear?” Social \& Cultural Geography 6 (6): 787-811. doi:10.1080/14649360500353004.

Johnston, Lynda. 2018. "Gender and Sexuality III: Precarious Places.” Progress in Human Geography 42 (6): 928-936. doi:10.1177/0309132517731256.

Jordan, Ana. 2018. "Masculinizing Care? Gender, Ethics of Care, and Fathers' Rights Groups." Men and Masculinities, May, 1097184X18776364. doi:10.1177/1097184X18776364.

Jupp, Eleanor. 2017. "Families, Policy and Place in Times of Austerity." Area 49 (3): 266272. doi:10.1111/area.12263.

Karamessini, Maria, and Gill Rubery. 2014. Women and Austerity: The Economic Crisis and the Future for Gender Equality. London: Routledge.

Longhurst, Robyn. 2000. "Geography and Gender: Masculinities, Male Identity and Men." Progress in Human Geography 24 (3): 439-444. doi:10.1191/030913200701540519. 
Precarious lives, precarious care: young men's caring practices in three coastal towns in England.

MacLeavy, Julie. 2011. 'A 'New Politics' of Austerity, Workfare and Gender? The UK Coalition Government's Welfare Reform Proposals." Cambridge Journal of Regions, Economy and Society 4 (3): 355-367. doi:10.1093/cjres/rsr023.

Marquardt, Nadine. 2016. "Learning to Feel at Home. Governing Homelessness and the Politics of Affect." Emotion, Space and Society 19 (May): 29-36. doi:10.1016/j.emospa.2016.03.004.

McDowell, Linda. 2003. Redundant Masculinities? : Employment Change and White Working Class Youth. Antipode Book Series 2. Malden, MA: Blackwell Pub.

Mcdowell, Linda. 2004. "Work, Workfare, Work/Life Balance and an Ethic of Care." Progress in Human Geography 28 (2): 145-163. doi:10.1191/0309132504ph478oa.

McDowell, Linda. 2005. "Love, Money, and Gender Divisions of Labour: Some Critical Reflections on Welfare-to-Work Policies in the UK." Journal of Economic Geography 5 (3): 365-379. doi:10.1093/jnlecg/lbh042.

McDowell, Linda. 2014. "The Sexual Contract, Youth, Masculinity and the Uncertain Promise of Waged Work in Austerity Britain." Australian Feminist Studies 29 (79): 31-49. doi:10.1080/08164649.2014.901281.

McDowell, Linda. 2017. "Youth, Children and Families in Austere Times: Change, Politics and a New Gender Contract." Area 49 (3): 311-316. doi:10.1111/area.12255.

McDowell, Linda, and Carl Bonner-Thompson. 2019. "The Other Side of Coastal Towns: Young Men's Precarious Lives on the Margins of England." Environment and Planning A: Economy and Space, November, 0308518X19887968. doi:10.1177/0308518X19887968.

McDowell, Linda, and Anna Harris. 2018. "Unruly Bodies and Dangerous Spaces: Masculinity and the Geography of 'Dreadful Enclosures." Urban Studies 56 (2): 419-433. doi:10.1177/0042098018810320.

McEwan, Cheryl, and Michael K. Goodman. 2010. "Place Geography and the Ethics of Care: Introductory Remarks on the Geographies of Ethics, Responsibility and Care." Ethics, Place \& Environment 13 (2): 103-112. doi:10.1080/13668791003778602.

McLoughlin, P.J. 2013. "Couch Surfing on the Margins: The Reliance on Temporary Living Arrangements as a Form of Homelessness amongst School-Aged Home Leavers." Journal of Youth Studies 16 (4): 521-545. doi:10.1080/13676261.2012.725839.

Milligan, Christine, and Janine Wiles. 2010. "Landscapes of Care." Progress in Human Geography 34 (6): 736-754. doi:10.1177/0309132510364556.

Nayak, Anoop. 2003. "Last of the 'Real Geordies'? White Masculinities and the Subcultural Response to Deindustrialisation." Environment and Planning D: Society and Space 21 (1): 7-25.

Nayak, Anoop. 2006. "Displaced Masculinities: Chavs, Youth and Class in the PostIndustrial City." Sociology 40 (5): 813-831. doi:10.1177/0038038506067508.

Nixon, Darren. 2009. “'I Can't Put a Smiley Face On': Working-Class Masculinity, Emotional Labour and Service Work in the "New Economy." Gender, Work \& Organization 16 (3): 300-322. doi:10.1111/j.1468-0432.2009.00446.x.

Parr, Hester. 2003. "Medical Geography: Care and Caring." Progress in Human Geography 27 (2): 212-221. doi:10.1191/0309132503ph423pr.

Pearson, Ruth, and Diane Elson. 2015. "Transcending the Impact of the Financial Crisis in the United Kingdom: Towards Plan F-a Feminist Economic Strategy." Feminist Review 109 (1): 8-30. doi:10.1057/fr.2014.42.

Pimlott-Wilson, Helena. 2017. "Individualising the Future: The Emotional Geographies of Neoliberal Governance in Young People's Aspirations." Area 49 (3): 288-295. doi:10.1111/area.12222. 
Precarious lives, precarious care: young men's caring practices in three coastal towns in England.

Power, Andrew, and Edward Hall. 2018. "Placing Care in Times of Austerity." Social \& Cultural Geography 19 (3): 303-313. doi:10.1080/14649365.2017.1327612.

Prassl, Jeremias, 2018 Humans as a service: the promise and perils of work in the gig economy Oxford: Oxford University Press.

Raghuram, P. 2016. "Locating Care Ethics beyond the Global North." ACME 15 (3): 511513.

Raghuram, Parvati, Clare Madge, and Pat Noxolo. 2009. "Rethinking Responsibility and Care for a Postcolonial World." Themed Issue: Postcoloniality, Responsibility and Care 40 (1): 5-13. doi:10.1016/j.geoforum.2008.07.007.

Razzu, Giovanni, and Carl Singleton. 2018. "Segregation and Gender Gaps in the United Kingdom's Great Recession and Recovery.” Feminist Economics 24 (4): 31-55. doi:10.1080/13545701.2018.1451907.

Rickey, Benedict, and John Houghton. 2009. "Solving the Riddle of the Sands: Regenerating England's Seaside Towns." Journal of Urban Regeneration \& Renewal 3 (1): 46-55.

Roberts, Steve. 2012. "Boys Will Be Boys ... Won't They? Change and Continuities in Contemporary Young Working-class Masculinities." Sociology 47 (4): 671-686. doi:10.1177/0038038512453791

Shildrick, T., and R. MacDonald. 2012. Poverty and Insecurity: Life in Low-Pay, No-Pay Britain. Studies in Poverty, Inequality and Social Exclusion Series. Policy Press. https://books.google.co.uk/books?id=0kFqDwAAQBAJ.

Sihto, Tiina. 2018. "Distances and Proximities of Care: Analysing Emotio-Spatial Distances in Informal Caring." Emotion, Space and Society 29 (November): 62-68. doi:10.1016/j.emospa.2018.10.002.

Staeheli, Lynn A, and Michael Brown. 2003. "Where Has Welfare Gone? Introductory Remarks on the Geographies of Care and Welfare." Environment and Planning A: Economy and Space 35 (5): 771-777. doi:10.1068/a35132.

Stenning, Alison. 2018. "Feeling the Squeeze: Towards a Psychosocial Geography of Austerity in Low-to-Middle Income Families." Geoforum, October. doi:10.1016/j.geoforum.2018.09.035.

Tarrant, Anna. 2018. "Care in an Age of Austerity: Men's Care Responsibilities in LowIncome Families." Ethics and Social Welfare 12 (1): 34-48. doi:10.1080/17496535.2017.1413581.

Thompson, Maddy. 2019. "Everything Changes to Stay the Same: Persistent Global Health Inequalities amidst New Therapeutic Opportunities and Mobilities for Filipino Nurses." Mobilities 14 (1): 38-53. doi:10.1080/17450101.2018.1518841.

van Lanen, Sander. 2018. "Encountering Austerity in Deprived Urban Neighbourhoods: Local Geographies and the Emergence of Austerity in the Lifeworld of Urban Youth." Geoforum, November. doi:10.1016/j.geoforum.2018.11.011.

Walby, S. 1986. Patriarchy at Work: Patriarchal and Capitalist Relations in Employment. Feminist Perspectives. Cambridge: Policy Press. https://books.google.co.uk/books?id=9YV0QgAACAAJ. 